\title{
Tourism in Nepal: A Historical Perspective and Present Trend of Development
}

\&ari Prasad Shrestha, Ph.D. \& Prami Shrestha

\section{Abstract}

Tourism is the movement or travel of people from one place to another; whether it is within their own country or to other countries, for pleasure, business, pilgrimage and other purpose. The evolution of tourism dates back to ancient times. In Nepal, tourism, despite having a long history was, developed since 1950s only. The recent trend of tourists' arrival in Nepal seems satisfactory. However, from the perspective of tourism based resources and its availability in the country seems rather pessimistic. To promote tourism sector and its contribution to socio-economic sector of the country, we need to utilize available resources properly and beneficially. For this, there is need of dynamic and tourism friendly policy and joint effort of the government and the private sector as well.

\section{Introduction}

Tourism refers to the movement or journey of human beings from one place to another, whether it is within one's own country or other countries. It can be for pleasure, business, pilgrimage and other purposes. The evolution of tourism dates back to ancient times. In Sanskrit literature, there are three terms for tourism, derived from the root "anta", which means going or leaving home for some other places. The three terms are:

Paryant (पर्यन्त) _ - It means going out for pleasure and knowledge.

Desant (देशान्त) _ _ It means going out of the country prominently for economic gain.

Tirthatan (तीर्थाटन ) - $\quad$ It means going out to places of religious merits.

The literal meaning of these three Sanskrit terms is that tourism denotes going out from house for pleasure and knowledge, going out of the country for economic gain and going out to places for religious purposes.

Traveling, in the remote past, was mandatory because the very survival and existence of primitive men depended on it. However, the advent of 
civilization brought about changes in human perception and the focus of traveling shifted from one of the necessity to a desire for adventure (Ranjit, 1976:17). Later, the introduction and development of the modern means of transportation and communication have contributed to tourism growth by facilitating and augmenting traveling activities (Shrestha, 1978:20). Today, tourism industry is rapidly growing worldwide and its role is significant in the socio-economic sector of all countries. Tourism is an important source of foreign exchange earnings, provides employment opportunities and helps in economic growth of the country.

The rapid growth of tourism in the world started only after the Second World War. The realization for the need of development in almost all countries, increasing liberalization of foreign exchange and travel restrictions, liberal policy of governments, the aspiration for international brotherhood, etc., are the main factors contributing for the rapid growth of tourism (Shrestha, 1978: 22). Other factors responsible for the enormous growth of international tourism are: availability of leisure time with the people, the rapid growth of population, the advent of Jet travel, the creation of low cost means of transport and communications, low cost hotel and restaurants, retirement age and increasing life expectancy, desire to know and see the unique life styles, traditions and cultures of people of different places, rising standard of living and so on. In the developed countries, tourism agencies are encouraging the people to travel by providing schemes of incentive travel. Agencies also provide credit plans to the people for traveling on installment basis as, "fly now pay later" arrangement (Encyclopedia Americana, 1976: 877). All these developments have led to the expansion of international tourism movement during the last few decades.

Regarding the modern concept, tourism is a relatively recent phenomenon in Nepal. Although the influx of visitors for different purposes was there from very early times. The study of the influx of foreign visitors to Nepal or the development of tourism in Nepal can be classified in the following three stages:

1. Historical Review of Tourism in Ancient Nepal.

2. Tourism after Unification of Nepal.

3. Tourism after 1950 . 


\section{Historical Review of Tourism in Ancient Nepal.}

Tourists have arrived in some form or the other from time immemorial in Nepal. In this context, first of all, it is pertinent to illustrate a legend. As far as the legend goes, 'Manjushree' had made the valley fit for human habitation by cutting the Chovar Hill of Kathmandu Valley with his sword and thereby letting the water flow out from within the valley (Sharma, 2033: 55-56, Bhandari 2030:17). Although Manjushree is said to have come either from India or China, yet he is regarded as the first tourist ever visiting Nepal $^{1}$.

During the early historical era too, famous visitors have been recorded as having visited Nepal. It has been illustrated in the chronicle that Gautam Buddha visited Nepal during the reign of Jitedasti, the seventh Kirat King, who stayed in the western part, near Swayambhu (Satyal 1, 1988: 28 and K.C. 1984: 18). The Great King of ancient India, Ashok too had visited Nepal. King Ashok visited Lumbini, the birth place of Lord Buddha, and built the Ashok Pillar there. He then came to Kathmandu valley and built similar pillars in different places (Satyal, 1988: 28).

In Nepalese history, the Lichchhavi period is regarded very significant from the tourism viewpoint. The Lichchhavi period started in 400 A.D. and there had been enormous progress of art and culture in the country during that period. In particular, architecture, paintings and sculpture were tremendously developed, while famous palaces like Kailashkut Bhawan, Managriha (Sharma, 2033: 121, 126) and Bhadradhiwas Bhawan (Shaha, 1998: 23) etc., were also built during that period. The way in which art and culture were developing in Nepal during that period inspired the Chinese travelers to come to Nepal and write about Nepal (Satyal, 1988: 29).

The marriage relations between Princess Bhrikuti, daughter of King Amshuvarma, and Srong-sten Gampo, the king of the northern state Lhasa (present Tibetan Autonomous Region of China) in 592 A.D. gave rise to the establishment of special relations between the two countries (Sharma 2033: 95 96). As a result, it was natural for the people of these countries to travel from one country to the other. Thereafter, Nepal was developed as the only route for a long period to visit China via Lhasa and travel from China to India via Lhasa. This led to the increase in arrivals of foreigners in Nepal (Sharma, 2033: 96 and Shakya, 2051: 11).

Famous Chinese traveler, Huien-Tsang, started the journey to India in 629 
A.D. According to historical evidence, after meeting King Harsabardhan of India, he returned to China via Nepal in 643 A.D. During his journey to Nepal, Huien-Tsang also visited Lumbini (Sharma, 2033: 89). The then Emperor of China is said to have sent his imperial envoys to India via Nepal in an attempt to strengthen the relations with King Harsabardhan of India. For example, in 643 A.D., Chinese envoy Li-Yi-Piao, came to Nepal via Lhasa and then visited India (Sharma, 2033: 89). Another Chinese envoy, Wang Hiuentse, frequently used to travel to and fro Nepal with his companions during 643-657 A.D. when he was envoy to India (Shakya, 2051: 11).

Buddhism preachers had visited Nepal during Lichchhavi period i.e. Shantarakshit in 742 A.D, Padma Sambhav in 474 A.D, Kamalsheel in 760 A.D, Atisha Dipankar in 1040 A.D and Milarepa in 1010 A.D.(Pradhan, 2045:136-62)

Along with the reign of the Mallas people from the western countries began coming to Nepal with an aim to spread and publicize Christianity. First of all Jao- Cabrall, a Portuguese, had entered Nepal via Bhutan with an aim to spread Christianity. Later, many Fathers came to Nepal with similar aims. Since 1737 A.D, King Jaya Prakash Malla provided written permission to Christians for the settlement and spreading of Christianity in Kantipur (Chhetri and Rayamajhi, 2061: 115-116)

The Malla period too is of great significance in the Nepalese history. The Mallas ruled over Nepal from around 750-1480 A.D. (Satyal, 1988: 29). A plethora of magnificent pagodas, palaces and houses reflect the richness of art and architecture during the Malla period. The Lichchhavis and the Mallas brought about total transformation in the life style of the people. The existing customs of the diverse ethnic groups and the various festivals celebrated round the year have their roots in the Lichchhavi and the Malla periods.

Against this background, foreign tourists are found to have been attracted and visited Nepal from time immemorial. During those days, foreign tourists visiting Nepal were Chinese, Tibetan and Indians and they used to visit Nepal specially with religious and commercial motives. Nepal was a famous pilgrimage for both the Chinese and Indians. The Chinese and Tibetan religious groups used to visit Lumbini, the birth place of Lord Buddha, while the Indian religious people used to visit holy places like 
Tourism in Nepal........ Dr. Shrestha \& Shrestha

Pashupati Nath, Baraha Kshetra, Muktinath, Gosainkunda, etc. Similarly, Nepalese traders used to go to Lhasa for business purposes and the Tibetan traders too are found to have come to Nepal in connection with their business activities. Thus, religious and trading sectors are found to have contributed significantly to the development of tourism in Nepal.

\section{Tourism after Unification of Nepal}

King Prithvinarayan Shah unified the scattered principalities into bigger Nepal in 1767 A.D.(1825 B.S.), thus, giving a new dimension to travel and tourism in the country's perspective. In the history of tourism development of Nepal, the visit of Captain Kirk Patric Mission in 1792 to Nepal also seems important. Although Kirk Patrick had come to Nepal as a military official to collect facts about Nepal, his book about Nepal "An Account of the Kingdom of Nepal" helped to introduce Nepal to outsiders.

After the treaty of Sugauli between the Nepal Government and the British East India Company in 1816 A.D. (Gautam, 2052: ka), a British Resident, Dr. Wallich, was appointed in Kathmandu for developing Nepal's relationship with British India. After this there were regular visits of British nationalities in Kathmandu. Rana Prime Minister Jung Bahadur's visit to Britain in 1850-51 A.D. brought the mysterious and fascinating Kingdom of Nepal into the limelight in Europe. During that time, several botanists and naturalists including Sir Brian Hodgson FRS, and Sir Joseph Hooker FRS had visited Nepal. Renowned European personalities like Silva Levy during the reign of Prime Minister Bir Shumshere and Percival London, during the reign of Prime Minister Chandra Shumsher had visited Nepal. Similarly, King George V and the Prince of Wales came to Nepal for hunting tigers in the terai forests in 1911 and 1921 respectively (Satyal, 1988: 32).

The earliest published record on foreign visitors to Nepal is found in Percival London's book 'Nepal', (Volume 11, Page 299 305) where 153 Europeans mostly British are listed to have visited Kathmandu in a period of 44 years from 1881 to 1925 (Gurung, $1978: 1$ ).

Despite these developments, the Rana autocracy isolated Nepal from external influence for a hundred and four years. During that period, Nepal was a 'forbidden land' for foreigners except for the small traders and Indian pilgrims. 


\section{Tourism After 1950}

After the advent of democracy in 1950, Nepal started to develop the different aspects of her social, economic and political life. Since that time, the door of Nepal has remained open to foreigners with the desire to visit Nepal in order to develop the tourist industry in the country. The role of mountain tourism is very significant in the overall tourism sector. In fact, tourism in Nepal began with mountain tourism. 1950s can be considered as the most important period in Nepal's tourism development. During the decade, of the world famous 14 over- $8000 \mathrm{~m}$ peaks 7 of the 8 over- $8000 \mathrm{~m}$ peaks in Nepal were for the first time successfully scaled i.e. Mt. Annapurna I, Mt. Everest, Mt. Cho Oyu, Mt. Makalu, Mt. Kanchenjunga, Mt. Manaslu, Mt. Lhotse, and Mt. Dhaulagiri in 1960 only. The first over-8000m peak to be conquered was Annapurna I by Maurice Herzog and Louis Lachenal of France on June 3, 1950. The world's highest peak Mount Sagarmatha (Everest) was successfully ascended by Tenzing Norgay Sherpa of Nepal and Sir Edmund Hillary of New Zealand on May 29, 1953. The first successful ascent of these two peaks did much to publicize Nepal as a destination to the world. The first successful ascent of the over- $8000 \mathrm{~m}$ peaks of Nepal led to an exceptional growth in mountaineering activities.

With the granting of membership of the United Nations Organization (UNO) in 1955, Non aligned Countries' Group since its very inception and the membership of different international agencies, it was easy for Nepal to be introduced in the world arena and in the same year, in 1955 world-renowned Thomas Cook and Sons brought a group of 60 tourists for a Nepal tour. These events contributed to the gradual influx of foreign tourists in Nepal. Therefore, the need was felt for conducting tourismrelated activities in a systematic manner and tourism management became a necessity

During this period, Nepal made concrete efforts to develop tourism. It created necessary institutional infrastructure needed to promote tourism, beginning from the establishment of the Tourism Development Board in 1957 culminating to the establishment of Nepal Tourism Board in 1998. First of all, Tourism Development Board, the body to deal with tourismrelated works, was established under the Department of Industry, in 1957. Later, in 1998, the Tourism Board was upgraded to the Department status, and the Tourism Department came under the Ministry of Construction and Communications and Transport. In 1959, Nepal joined the membership 
of International Union of Official Travel Organization (IUOTO), present name, World Tourism Organization (WTO), and Pacific Area Travel Association (PATA) in 1963. The number of foreign visitors to Nepal has been increasing at a rather high yearly rate since the entrance in these international organizations. The main factors for such substantial increase in the influx of the tourists were the intensive promotional activities, expansion of the hotel accommodations, development of modern banking system, the improved transport and communication facilities, increase in the touristic resorts and facilities and so on.

There was no plan and policy regarding tourism in Nepal till 1950s. For the first time the written study on tourism was made in late 1950s. In Nepal "General Plan for the Organization of Tourism of Nepal" prepared by French national, George Lebrec, in 1959, was the first tourism plan, which was prepared with the help of the French Government. In this plan, Lebrec has recommended to make brochures, posters, postage stamps depicting the Himalayan peaks and flora and fauna and to use films and documentaries prepared by the mountaineering expedition for promoting tourism in Nepal and the establishment of separate tourism offices. Later, George Lebrec visited Nepal in 1964 and 1966 and presented two reports on tourism entitled "Report on the Development of Tourism" and "Report on Tourism in Nepal" respectively. In these reports Lebrec had recommended that tourism in Nepal had stated growing at a faster pace (Shrestha, 2000: 47). Later in 1965 Sir Eric Franklin from USA came to Nepal for the supervision of Tourism Department (Chhetri and Rayamajhi, 2061: 120).

In 1962, for the first time the Tourism Department started keeping the statistics of the foreign tourists coming into Nepal. In 1967, Tourism Department came under the Ministry of Industry and Commerce. To facilitate and provide necessary information to the foreign tourists entering Nepal, the Tourism Department established information centers at Tribhuvan International Airport, Basantpur in Kathmandu, Bhairahawa, Birgunj, Kakarbhitta and Janakpur. With the loan assistance of the Asian Development Bank, the tourism Department established the Tourism Infrastructure Development Project, within the department, in Pokhara, Gorkha and Kathmandu.

Nepal Tourism Development Committee was established in 1969 for formulating the tourist policy as well as to draw a long term development plan for this sector. This committee is composed of a member of the Royal 
family along with the representatives of the important executing ministries, travel and hotel industries. Reorganization of this committee was done with 10 members under the Chairmanship of HRH, Prince Himalaya Bir Bikram Shah, in mid 1971.

With the joint effort of UNDP and ILO, Hotel Management and Tourism Training Centre wasestablished in 1972 with a view to produce trained manpower in tourism sector. This center was renamed as Nepal Academy of Tourism and Hotel Management (NATHM) in 1999. .

Further, plans and policies were also defined for creating conducive environment for the growth of the tourism sector. In this respect, the notable efforts were the Tourism Master Plan 1972, Review of the Master Plan 1984, and defining of Tourism Policy in 1995. For the planned development of tourism in Nepal, Nepal government joined hands with the German government to prepare the 20-year 'Tourism Master Plan, 1972'. According to the recommendation of this master plan, a separate Ministry of Tourism was established in 1977 with a view to enhance tourism properly in the country. The Tourism Ministry was named Tourism and Civil Aviation Ministry in 1991, and Culture, Tourism and Civil Aviation Ministry in 2000. In between, high level bodies like Tourism Promotion Committee and Tourism Council were formed to create the necessary paraphernalia. These activities contributed to generate important market for Nepalese tourism and the industry marched ahead in a significant manner.

The Public-Private Partnership for the development of tourism in Nepal led to the establishment of the Nepal Tourism Board in 1998. The government decided to dissolve Tourism Department, in 1999 and its functions were transferred to the Tourism Ministry and Nepal Tourism Board. Presently, Tourism and Civil Aviation Ministry formulates the tourism related policies and Nepal Tourism Board does the work of promoting tourism in the country.

After a considerable gap of 13 years, after the "Tourism Policy, 1995", with a view to timely reform and change the tourism sector the government brought the second "Tourism Policy, 2008" (2065 B.S), in 2008. The special features of this new policy include attracting more tourists, marking "Visit Nepal Year" or "Nepal Tourism Year" in designated years. It also envisages making Nepal an all season destination for tourists. Later the government declared the 2011 as "Tourism Year 2011" with a view to 
bring $10,00,000$ tourists in the country. However, in the year 2011 only $7,35,932$ tourists entered the country but due to this slogan more publicity in the world market took place and many infrastructure developments in the tourism sector were made.

\section{TREND OF TOURISM DEVELOPMENT IN NEPAL}

Sound growth has been recorded in Nepal's tourism industry in the past five decades with the number of tourists visiting the country growing from 6,179 in 1962 to $6,02,867$ in the year 2010. Since 1962, Department of Tourism had started maintaining the statistics of tourism and the number of foreign visitors to Nepal has been increasing every year since the beginning year, 1962, except in the years 1965, 1981, 1984, 1989, 1993, 2000, 2001, 2002, 2005 and 2008.

The tourist arrival in 1962 was 6179 and after a decade in 1972 it reached 52,930 , which was an increase by 8.6 times. Similarly, in the following decades in 1982, 1992 and 2002 the total number of tourist arrivals increased $1,75,448,3,34,353$ and $2,75,468$ respectively which was an increase by $28.4,54.1$ and 44.6 times respectively in every decades in comparison to the year 1962. In the year 2010, the number of tourists reached $6,02,867$ by recording a growth of 18.2 percent over 2009 which was the highest figure of tourist arrival in Nepal until the year 2010. The total number of tourist arrivals 6,02,867 in the year 2010 reached 98 times increase in comparison to the beginning year 1962.

Table No. 1 : Number of Tourists Arrival in Nepal 1962-2010

\begin{tabular}{|c|c|c|c|}
\hline Year & $\begin{array}{c}\text { Number of } \\
\text { Tourists }\end{array}$ & ARPC & Index \\
\hline 1962 & 6179 & - & 100 \\
\hline 1965 & 9388 & 15.0 & 152 \\
\hline 1970 & 45970 & 37.4 & 744 \\
\hline 1975 & 92440 & 15.0 & 1496 \\
\hline 1980 & 162897 & 12.0 & 2636 \\
\hline 1985 & 180989 & 2.1 & 2929 \\
\hline 1990 & 254885 & 7.1 & 4125 \\
\hline 1995 & 363395 & 7.4 & 5881 \\
\hline 2000 & 463646 & 5.0 & 7504 \\
\hline 2001 & 361237 & -22.1 & 5846 \\
\hline
\end{tabular}




\begin{tabular}{|c|c|c|c|}
\hline 2002 & 257468 & -23.7 & 4167 \\
\hline 2003 & 338132 & 22.7 & 5472 \\
\hline 2004 & 385297 & 13.9 & 6236 \\
\hline 2005 & 375398 & -2.6 & 6075 \\
\hline 2006 & 383926 & 2.3 & 6213 \\
\hline 2007 & 526705 & 37.2 & 8524 \\
\hline 2008 & 500277 & -5.0 & 8096 \\
\hline 2009 & 509956 & 1.9 & 8253 \\
\hline 2010 & 602867 & 18.2 & 9757 \\
\hline
\end{tabular}

Source: Nepal Tourism Statistics 2010, Ministry of Tourism and Civil Aviation, Govt. of Nepal, 2010.

Tourist arrivals in Nepal, despite showing a steady trend on most occasions have also shown relative stagnancy and fluctuations. For example, the number of tourist arrivals decreased by 1.5 percent, in 1965 , due to tension between Pakistan and India. There has been a relative stagnancy during the period 1978-82 due to the democracy movement in Nepal and oil crisis which led to decline in world tourism flow. Tourist arrivals declined in the year 1989 due to trade and transit dispute between Nepal and India. Decline in tourist arrivals in 1993 may be attributed to a host of reasons viz. like the increase in Visa fees, limited air seat capacity, THAI and PIA aircraft accidents, increasing pollution in Kathmandu and its international publicity, lack of promotional activities abroad, destruction caused by floods and landslides and numerous strikes and 'Bandha' as a part of political unrest particularly after the death of Madan Bhandari.

In the years 2000, 2001 and 2002 there has been a continuous decrease in tourist arrivals in the country and it is attributed to the hijacking of an Indian Airlines aircraft on 24 December 1999 on route to Delhi from Kathmandu, attraction for Indian tourists to visit Thailand, Singapore, Malaysia rather than Nepal, increasing Maoist insurgency and unnecessary 'Bandhas' directly affected tourism. Similarly, tourist arrival was decreased by 5.0 in 2008 due to the strike in Swornabhumi International Airport, in Bangkok, Thailand. Thus, both internal and external disturbances highly influenced tourist arrival in Nepal and though Nepal may not have much control over externalities, we should manage and control internal factors if we really want to develop tourism steadily (Shrestha, 2000:147-148). 
Tourism in Nepal......... Dr. Shrestha \& Shrestha

Gender-wise Tourist's Trend

The gender wise trend of tourist arrivals in Nepal shows that the number of male touristss is always larger than that of female tourists, which indicates male preference for Nepal. In the beginning years the number of female tourists was bigger. In the year 1962 almost half the tourists (47.7) were females, but in the following year it was in a decreasing trend and the ratio reached at the lowest 31.3 percent in 2005. Since 2006 there has been a gradual increase in the ratio and the share of female tourists reached 44.8 percent in 2007. In the year 2010 the ratio of male and female tourists' arrivals in Nepal were 60.0 and 40.0 respectively of the total arrivals. It indicates that there is a need to develop appropriate products to attract the female visitors.

Table No. 2 : Tourists Arrival in Nepal by Gender 1962-2010

\begin{tabular}{|c|c|c|c|}
\hline \multirow{2}{*}{ Year } & \multicolumn{2}{|c|}{ Gender } & $\begin{array}{c}\text { Total } \\
\text { Arrivals }\end{array}$ \\
\cline { 2 - 3 } & Male & Female & 6179 \\
\hline 1962 & $3231(52.3)$ & $2948(47.7)$ & 9388 \\
\hline 1965 & $5226(55.7)$ & $4162(44.3)$ & 45970 \\
\hline 1970 & $26157(56.9)$ & $19813(43.1)$ & 92440 \\
\hline 1975 & $55741(60.3)$ & $36699(39.7)$ & 162897 \\
\hline 1880 & $100006(61.4)$ & $62891(38.6)$ & 180985 \\
\hline 1885 & $113863(62.8)$ & $67426(37.2)$ & 254885 \\
\hline 1990 & $155311(60.9)$ & $99574(39.1)$ & 363395 \\
\hline 1995 & $224769(61.9)$ & $138626(38.1)$ & 463646 \\
\hline 2000 & $266937(57.6)$ & $196709(42.4)$ & 361237 \\
\hline 2001 & $213465(59.1)$ & $147772(40.9)$ & 275468 \\
\hline 2002 & $174710(63.4)$ & $100758(36.5)$ & 338132 \\
\hline 2003 & $204732(60.5)$ & $133400(39.5)$ & 385297 \\
\hline 2004 & $255,303(66.3)$ & $129994(33.7)$ & 375398 \\
\hline 2005 & $257972(68.7)$ & $117426(31.3)$ & 383926 \\
\hline 2006 & $218818(57.0)$ & $165108(43.0)$ & 526705 \\
\hline 2007 & $290688(55.2)$ & $236017(44.8)$ & 500277 \\
\hline 2008 & $286983(57.4)$ & $213294(42.6)$ & 509956 \\
\hline 2009 & $288155(56.5)$ & $221801(43.5)$ & 602867 \\
\hline 2010 & $361611(60.0)$ & $241256(40.0)$ & \\
\hline
\end{tabular}

Note: Figures in parenthesis represent percentage of the total

Source: Nepal Tourism Statistics, 2010, Ministry of Tourists and Civil Aviation, Govt. of Nepal, 2010. 


\section{Age wise Tourist Trend}

According to the age wise tourist arrivals trend in Nepal, in the early periods the highest share was occupied by the younger age group 16-30 followed by the age group of 31-45, 46-60 \& over and 0-15 since 1965 to 1991 except in 1985. But since the year 1992 to 2010 the trend showed that the age group of 31-45 has a higher share and age group of 16-30, 46$60,61 \&$ over and 0-15 secured second, third, fourth and fifth position. In the year 2010 among the total tourist arrivals in Nepal 58.3 percent were under the age of 45 and 39.4 percent were over the age of 45 years and the rest 2.3 percent tourists has not specified the age group. It shows that Nepal is popular both for youths and adults.

Table No. 3 : Tourist Arrival in Nepal by Age Group 1962-2010.

\begin{tabular}{|c|c|c|c|c|c|c|c|}
\hline Year & 0-15 & $16-30$ & $31-45$ & $46-60$ & $\begin{array}{l}61 \& \\
\text { over }\end{array}$ & $\begin{array}{c}\text { Not } \\
\text { Specified }\end{array}$ & $\begin{array}{c}\text { Total } \\
\text { Arrivals }\end{array}$ \\
\hline 1962 & & & & & & & 6179 \\
\hline \multirow{2}{*}{1965} & 150 & 2563 & 2375 & 2272 & 2028 & & \multirow{2}{*}{9388} \\
\hline & $(1.6)$ & (27.3) & (25.3) & $(24.2)$ & (21.6) & & \\
\hline \multirow{2}{*}{1970} & 1613 & 16302 & 11240 & 9559 & 7256 & & \multirow{2}{*}{45970} \\
\hline & $(3.5)$ & (35.5) & $(24.5)$ & (20.8) & (15.7) & & \\
\hline \multirow{2}{*}{1975} & 2958 & 36514 & 27177 & 16824 & 8967 & & \multirow{2}{*}{92440} \\
\hline & $(3.2)$ & (29.5) & (29.4) & (18.2) & $(9.7)$ & & \\
\hline \multirow{2}{*}{1880} & 6914 & 59724 & 48786 & 31544 & 15929 & & \multirow{2}{*}{162897} \\
\hline & $(4.2)$ & (36.7) & (29.9) & (19.4) & $(9.8)$ & & \\
\hline \multirow{2}{*}{1885} & 9497 & 58861 & 61528 & 33520 & 17583 & & \multirow{2}{*}{180989} \\
\hline & $(5.2)$ & $(32.5)$ & $(34.0)$ & $(18.6)$ & $(9.7)$ & & \\
\hline \multirow{2}{*}{1990} & 10620 & 85903 & 82292 & 49388 & 26682 & & \multirow{2}{*}{254885} \\
\hline & $(4.2)$ & $(33.7)$ & $(32.3)$ & (19.4) & (10.4) & & \\
\hline \multirow{2}{*}{1995} & 22878 & 106603 & 120212 & 76647 & 37055 & & \multirow{2}{*}{363395} \\
\hline & $(6.3)$ & $(29.3)$ & (33.1) & (21.1) & (10.2) & & \\
\hline \multirow{2}{*}{2000} & 19136 & 119816 & 148063 & 125140 & 51491 & & \multirow{2}{*}{463464} \\
\hline & $(4.1)$ & $(25.8)$ & $(31.9)$ & $(27.0)$ & (11.1) & & \\
\hline \multirow{2}{*}{2001} & 14608 & 95801 & 115678 & 93621 & 41525 & & \multirow{2}{*}{361237} \\
\hline & $(4.0)$ & $(26.5)$ & $(32.0)$ & (25.9) & (11.5) & & \\
\hline
\end{tabular}




\begin{tabular}{|c|c|c|c|c|c|c|c|}
\hline 2002 & $\begin{array}{c}12425 \\
(4.5)\end{array}$ & $\begin{array}{l}67774 \\
(24.6)\end{array}$ & $\begin{array}{l}99622 \\
(36.2)\end{array}$ & $\begin{array}{l}67017 \\
(24.3)\end{array}$ & $\begin{array}{l}28630 \\
(10.4)\end{array}$ & & 275468 \\
\hline 2003 & $\begin{array}{l}16056 \\
(4.7)\end{array}$ & $\begin{array}{l}78357 \\
(23.2)\end{array}$ & $\begin{array}{l}99740 \\
(29.5)\end{array}$ & $\begin{array}{l}85753 \\
(25.4) \\
\end{array}$ & $\begin{array}{l}58226 \\
(17.2)\end{array}$ & & 338132 \\
\hline 2004 & $\begin{array}{l}38734 \\
(10.1) \\
\end{array}$ & $\begin{array}{l}84125 \\
(21.8) \\
\end{array}$ & $\begin{array}{r}128267 \\
(33.3) \\
\end{array}$ & $\begin{array}{l}96920 \\
(25.2) \\
\end{array}$ & $\begin{array}{c}37251 \\
(9.7) \\
\end{array}$ & & 385297 \\
\hline 2005 & $\begin{array}{r}30429 \\
(8.1) \\
\end{array}$ & $\begin{array}{l}57115 \\
(21.2) \\
\end{array}$ & $\begin{array}{c}114103 \\
(30.4)\end{array}$ & $\begin{array}{c}106077 \\
(28.3)\end{array}$ & $\begin{array}{l}67674 \\
(18.0)\end{array}$ & & 375398 \\
\hline 2006 & $\begin{array}{c}37433 \\
(9.8) \\
\end{array}$ & $\begin{array}{l}75626 \\
(19.7) \\
\end{array}$ & $\begin{array}{r}123541 \\
(32.2) \\
\end{array}$ & $\begin{array}{l}95260 \\
(24.8) \\
\end{array}$ & $\begin{array}{l}52066 \\
(13.6) \\
\end{array}$ & & 383926 \\
\hline 2007 & $\begin{array}{c}38870 \\
(7.4)\end{array}$ & $\begin{array}{l}112879 \\
(21.4)\end{array}$ & $\begin{array}{c}164488 \\
(31.2) \\
\end{array}$ & $130756(24.8)$ & $\begin{array}{l}69927 \\
(13.3)\end{array}$ & $\begin{array}{l}9785 \\
(1.9) \\
\end{array}$ & 526705 \\
\hline 2008 & $\begin{array}{c}42581 \\
(8.5)\end{array}$ & $\begin{array}{c}106596 \\
(21.3)\end{array}$ & $\begin{array}{c}150171 \\
(30.0)\end{array}$ & $121387(24.3)$ & $\begin{array}{l}60531 \\
(12.1)\end{array}$ & $\begin{array}{l}19011 \\
(3.8) \\
\end{array}$ & 500277 \\
\hline 2009 & $\begin{array}{l}84891 \\
(16.6)\end{array}$ & $\begin{array}{r}140805 \\
(27.6)\end{array}$ & $\begin{array}{r}141955 \\
(27.8)\end{array}$ & $\begin{array}{l}99197 \\
(19.5) \\
\end{array}$ & $\begin{array}{c}39639 \\
(7.8)\end{array}$ & $\begin{array}{l}3470 \\
(0.7) \\
\end{array}$ & 509956 \\
\hline 2010 & $\begin{array}{c}41156 \\
(6.8) \\
\end{array}$ & $\begin{array}{r}120395 \\
(20.0)\end{array}$ & $\begin{array}{c}189852 \\
(31.5) \\
\end{array}$ & $\begin{array}{c}172800 \\
(28.7) \\
\end{array}$ & $\begin{array}{l}64593 \\
(10.7) \\
\end{array}$ & $\begin{array}{l}14071 \\
(2.3) \\
\end{array}$ & 602867 \\
\hline
\end{tabular}

Note: Figures in parenthesis represent percentage of the total

Source : Nepal Tourism Statistics, 2010, Ministry of Tourists and Civil Aviation, Govt. of Nepal, 2010.

\section{Nationality Trend of Tourism}

In terms of nationality, the largest number of tourists coming to Nepal is from India and other major nationalities include UK, USA, Sri Lanka, Japan, Germany, France, etc. India has an increasing trend from 17.8 percent share in 2001 to 25.5 percent in 2003 and 2005. The highest share of 33.2 percent India nationalities were recorded in the year 1984 . According to the data presented in Table no. 4 the highest percent of tourist arrivals in Nepal in 2010 was from India with 20.1 percent share and other major market for Nepal among top ten nations ${ }^{1}$ are Sri Lanka $(7.6 \%)$, USA (6.0\%), UK (5.8\%), France (4.1\%), Japan (3.9\%), Germany (3.7\%), Australia (2.7\%), Spain (2.3\%) and Netherland (2.2\%) respectively. 
Table No. 4 : Tourist Arrival in Nepal by Major Nationality 2001-2010

\begin{tabular}{|c|c|c|c|c|c|c|c|c|c|c|c|c|c|c|c|c|c|c|}
\hline Year & Australia & Australia & Canada & Denmark & France & Germany & India & Italy & Japan & Netherlands & Spain & Switzerland & Srilanka & U.S.A. & U.K & Others & \begin{tabular}{|c|} 
Not \\
Specified \\
\end{tabular} & Total \\
\hline 2001 & 10455 & 4164 & 7068 & 3854 & 21187 & 21577 & 64320 & 8745 & 28830 & 13662 & 5897 & 5649 & 9844 & 32052 & 33533 & 90400 & & 361237 \\
\hline$\%$ & 2.9 & 1.2 & 2.0 & 1.1 & 5.9 & 6.0 & 17.8 & 2.4 & 8.0 & 3.8 & 1.6 & 1.6 & 2.7 & 8.9 & 9.3 & 25.0 & - & 100. \\
\hline 2002 & 7159 & 3140 & 3747 & 2040 & 13376 & 15774 & 66777 & 8057 & 23223 & 8306 & 5267 & 3352 & 9805. & 17518 & 21007 & 66920 & & 275468 \\
\hline$\%$ & 2.6 & 1.1 & 1.4 & 0.7 & 4.9 & 5.7 & 24.2 & 2.9 & 8.4 & 3.0 & 1.9 & 1.2 & 3.6 & 6.4 & 7.6 & 24.3 & & 100. \\
\hline 2003 & 7916 & 3025 & 4154 & 2178 & 15865 & 14866 & 86363 & 8243 & 27412 & 8443 & 8265 & 3246 & 13930 & 18838 & 22101 & 93287 & & 338132 \\
\hline$\%$ & 2.3 & 0.9 & 1.2 & 0.6 & 4.7 & 4.4 & 25.5 & 2.4 & 8.1 & 2.5 & 2.4 & 1.0 & 4.1 & 5.6 & 6.5 & 27.6 & & 100. \\
\hline 2004 & 9671 & 4341 & 4825 & 2633 & 18938 & 16025 & 90326 & 12376 & 24231 & 11160 & 11767 & 3788 & 16124 & 20680 & 24667 & 113745 & & 385297 \\
\hline$\%$ & 2.5 & 1.1 & 1.3 & 0.7 & 4.9 & 4.2 & 23.4 & 3.2 & 6.3 & 2.9 & 3.1 & 1.0 & 4.2 & 5.4 & 6.4 & 29.5 & & 100. \\
\hline 2005 & 7093 & 3007 & 4168 & 1770 & 14108 & 14345 & 95685 & 8785 & 18239 & 8947 & 8891 & 3163 & 18770 & 18539 & 25151 & 124737 & & 375398 \\
\hline$\%$ & 1.9 & 0.8 & 1.1 & 0.5 & 3.8 & 3.8 & 25.5 & 2.3 & 4.9 & 2.4 & 2.4 & 0.8 & 5.0 & 4.9 & 6.7 & 33.2 & 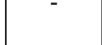 & 100. \\
\hline 2006 & 8231 & 3474 & 4733 & 1956 & 14835 & 14361 & 93722 & 7736 & 22242 & 7207 & 10377 & 3559 & 27413 & 19833 & 22708 & 120732 & 4005 & 383926 \\
\hline$\%$ & 2.1 & 0.9 & 1.2 & 0.5 & 3.9 & 3.7 & 24.4 & 2.0 & 5.8 & 1.9 & 2.7 & 0.9 & 7.1 & 5.2 & 5.9 & 31.4 & 1.0 & 100. \\
\hline 2007 & 12369 & 4473 & 7399 & 3157 & 20250 & 21323 & 96010 & 11243 & 27058 & 10589 & 15672 & 5238 & 49947 & 29783 & 32367 & 176312 & 3515 & 526705 \\
\hline$\%$ & 2.3 & 0.8 & 1.4 & 0.6 & 3.8 & 4.0 & 18.2 & 2.1 & 5.1 & 2.0 & 3.0 & 1.0 & 9.5 & 5.7 & 6.1 & 33.5 & 0.7 & 100. \\
\hline 2008 & 19846 & 3540 & 8132 & 3847 & 22402 & 18552 & 91177 & 7914 & 23383 & 10900 & 13851 & 5186 & 37817 & 30076 & 33658 & 171989 & 4007 & 500277 \\
\hline$\%$ & 2.8 & 0.7 & 1.6 & 0.8 & 4.5 & 3.7 & 18.2 & 1.6 & 4.7 & 2.2 & 2.8 & 1.0 & 7.6 & 6.0 & 6.7 & 34.4 & 0.8 & 100. \\
\hline 2009 & 15461 & 3245 & 8965 & 4464 & 22154 & 19246 & 93884 & 7982 & 22445 & 11147 & 13006 & 5281 & 36362 & 32042 & 35382 & 172846 & 6043 & 509956 \\
\hline$\%$ & 3.0 & 0.6 & 1.8 & 0.9 & 4.3 & 3.8 & 18.4 & 1.6 & 4.4 & 2.2 & 2.6 & 1.0 & 7.1 & 6.3 & 6.9 & 33.9 & 1.2 & 100. \\
\hline 2010 & 16243 & 3389 & 9322 & 4359 & 24550 & 22583 & 120898 & 10226 & 23332 & 13471 & 13712 & 5320 & 45531 & 36425 & 35091 & 214950 & 3465 & 602867 \\
\hline$\%$ & 2.7 & 0.6 & 1.5 & 0.7 & 4.1 & 3.7 & 20.1 & 1.7 & 3.9 & 2.2 & 2.3 & .9 & 7.6 & 6.0 & 5.8 & 35.7 & 0.6 & 100. \\
\hline
\end{tabular}


Purpose wise Trend of Tourists

Most of the tourists visiting Nepal come for holiday/pleasure purpose. Since the beginning above 75 percent tourists of arriving Nepal came with the holiday/pleasure purpose and it remained so until 1989. In recent years, the number of tourists coming for holiday/pleasure has been decreasing, for example in 2009 and 2010 the tourists coming for holiday/ pleasure purpose are only 8.0 and 12.4 percent only. And the number of tourists coming for trekking/mountaineering purpose has been increasing with the share growing from $0.4 \%$ in 1965 to $27.9 \%$ in 2001 . According to the data for 2009 , most of the incoming tourists $(26.1 \%)$ come for mountain tourism. This proves that mountain tourism is the prominent tourism product of Nepal and the country is the market leader in this sector (Sherpa and Shrestha, 2011:81)

Table No.5 : Tourist Arrivals in Nepal by Purpose of Visit 1962-2010.

\begin{tabular}{|c|c|c|c|l|c|l|l|l|c|c|}
\hline Year & $\begin{array}{c}\text { Holiday/ } \\
\text { Pleasure }\end{array}$ & $\begin{array}{c}\text { Trekking \& } \\
\text { Mountaineering }\end{array}$ & Business & Pilgrimage & Official & $\begin{array}{c}\text { Convention/ } \\
\text { Conference }\end{array}$ & Rafting & Others & $\begin{array}{c}\text { Not } \\
\text { Specified }\end{array}$ & Total \\
\hline \multirow{2}{*}{1962} & & & & & & & & & & 6179 \\
& & & & & & & & & & $(100)$ \\
\hline \multirow{2}{*}{1965} & 8815 & 40 & 160 & & 372 & & & 1 & & 9388 \\
& $(93.9)$ & $(0.4)$ & $(1.7)$ & & 4.0 & & & $(0.0)$ & & $(100)$ \\
\hline \multirow{2}{*}{1970} & 4188 & 556 & 918 & & 1528 & & & 1087 & & 45970 \\
& $(91.1)$ & $(1.2)$ & $(2.0)$ & & 3.3 & & & $(2.4)$ & & $(100)$ \\
\hline \multirow{2}{*}{1975} & 20124 & 12587 & 4911 & & 4227 & & & 591 & & 92440 \\
& $(75.9)$ & $(13.6)$ & $(5.3)$ & & $(4.6)$ & & & $(0.6)$ & & $(100)$ \\
\hline \multirow{2}{*}{1980} & 130600 & 19302 & 5491 & & 4654 & & & 2850 & & 162897 \\
& $(80.2)$ & $(11.8)$ & $(3.4)$ & & $(2.9)$ & & & $(1.7)$ & & $(100)$ \\
\hline \multirow{2}{*}{1985} & 128217 & 28707 & 10416 & & 9230 & & & 4419 & & 180989 \\
& $(70.8)$ & $(15.9)$ & $(5.8)$ & & $(5.1)$ & & & $(2.4)$ & & $(100)$ \\
\hline
\end{tabular}




\begin{tabular}{||c|c|c|c|c|c|c|c|c|c|c|}
\hline \multirow{2}{*}{1990} & $\begin{array}{c}161839 \\
(63.5)\end{array}$ & $\begin{array}{c}39999 \\
(15.7\end{array}$ & $\begin{array}{c}11728 \\
(4.6)\end{array}$ & $\begin{array}{c}6713 \\
(2.6)\end{array}$ & $\begin{array}{c}26578 \\
(10.4)\end{array}$ & $\begin{array}{c}2838 \\
(1.1)\end{array}$ & $\begin{array}{c}26578 \\
(10.4)\end{array}$ & $\begin{array}{c}254885 \\
(100)\end{array}$ \\
\hline \multirow{2}{*}{1995} & 183207 & 84787 & 21829 & 5257 & 20040 & 5272 & & 42953 & $(11.8)$ & 363395 \\
& $(50.4)$ & $(23.3)$ & $(6.0)$ & $(1.4)$ & $(5.5)$ & $(1.5)$ & & $100)$ \\
\hline \multirow{2}{*}{2000} & 255889 & 118780 & 29454 & 15801 & 20832 & 5599 & & 17291 & $(3.7)$ & 463646 \\
& $(55.2)$ & $(25.6)$ & $(6.4)$ & $(3.4)$ & $(4.5)$ & $(1.2)$ & $(100)$ \\
\hline \multirow{2}{*}{2001} & 187022 & 100828 & 18528 & 13816 & 18727 & 0 & & 22316 & & 361237 \\
& $(51.8)$ & $(27.9)$ & $(5.1)$ & $(3.8)$ & 5.2 & $(0.0)$ & $(6.2)$ & $(100)$ \\
\hline \multirow{2}{*}{2002} & 110143 & 59279 & 16990 & 12366 & 17783 & 0 & & 58907 & $(21.4)$ & 275468 \\
& $(40.0)$ & $(21.5)$ & $(6.2)$ & $(4.5)$ & $(6.5)$ & $(0.0)$ & & $(100)$ \\
\hline \multirow{2}{*}{2003} & 97904 & 65721 & 19387 & 21395 & 21967 & 0 & & 111758 & $(33.1)$ & 338132 \\
& $(29.0)$ & $(19.4)$ & $(5.7)$ & $(6.3)$ & $(6.5)$ & $(0.0)$ & & $(100)$ \\
\hline \multirow{2}{*}{2004} & 167262 & 69442 & 13948 & 45664 & 17088 & 0 & & 71893 & $(18.7)$ & 385297 \\
& $(43.4)$ & $(18.0)$ & $(3.6)$ & $(11.9)$ & $(4.4)$ & $(0.0)$ & & $(100)$ \\
\hline \multirow{2}{*}{2005} & 160259 & 61488 & 21992 & 47621 & 16859 & 0 & & 67179 & $(17.9)$ & 375398 \\
& $(42.7)$ & $(41.4)$ & $(5.9)$ & $(12.7)$ & $(4.5)$ & $(0.0)$ & & $(100)$ \\
\hline \multirow{2}{*}{2006} & 145802 & 66931 & 21066 & 59298 & 18063 & 0 & & 72766 & $(13.8)$ & 383926 \\
& $(27.7)$ & $(12.7)$ & $(4.0)$ & $(11.3)$ & $(3.4)$ & $(0.0)$ & & $(100)$ \\
\hline \multirow{2}{*}{2007} & 217815 & 101320 & 24487 & 53594 & 21670 & 8019 & 65 & 78579 & 22156 & 526705 \\
& $(41.4)$ & $(19.2)$ & $(4.6)$ & $(10.0)$ & $(4.1)$ & $(1.5)$ & $(0.0)$ & $(14.9)$ & $(4.2)$ & $(100)$ \\
\hline \multirow{2}{*}{2008} & 148180 & 104822 & 23039 & 45091 & 43044 & 6938 & 243 & 99391 & 29529 & 500277 \\
& $(29.6)$ & $(21.0)$ & $(4.6)$ & $(9.0)$ & $(8.6)$ & $(1.4)$ & $(0.0)$ & $(19.9)$ & $(5.9)$ & $(100)$ \\
\hline \multirow{2}{*}{2009} & 40992 & 132929 & 22758 & 51542 & 24518 & 9985 & 285 & 186849 & 40098 & 509956 \\
& $(8.0)$ & $(26.1)$ & $(4.5)$ & $(10.1)$ & $(4.8)$ & $(2.0)$ & $(0.1)$ & $(36.6)$ & $(7.9)$ & $(100)$ \\
\hline \multirow{2}{*}{2010} & 63082 & 70218 & 21377 & 101335 & 26374 & 9627 & 730 & 252473 & 57651 & 602867 \\
& $(12.4)$ & $(13.8)$ & $(4.2)$ & $(19.9)$ & $(5.2)$ & $(1.9)$ & $(0.1)$ & $(49.5)$ & $(11.3)$ & $(118.2)$ \\
\hline
\end{tabular}

Note: Figures in parenthesis represent percentage of the total

Source : Nepal Tourism Statistics, 2010, Ministry of Tourists and Civil Aviation, Govt. of Nepal, 2010. 


\section{Seasonal Trend of Tourist Arrivals}

The tourist flow in Nepal is generally confined during the Spring and Autumn seasons. March, April of Spring season and October, November of Autumn season, these four months are peak seasons for tourist coming to Nepal. Among $z_{\frac{\pi}{8}}$ the total tourists arrival in a year about 13 percent tourists visit the country in the month of October followed by March (10.3\%), November (10.0\%) and April (7.8\%) respectively. Similarly, June and July are recorded as lowest tourist arrival months. Generally tourists are more concentrated in four months March, April, October and November; however, recently there is indication that tourists are coming to Nepal slowly in other seasons too.

Table No 6 : Tourist Arrival by Month 1962-2010.

\begin{tabular}{|c|c|c|c|c|c|c|c|c|c|c|c|c|c|}
\hline Year & January & February & March & April & May & June & July & August & September & October & November & December & $\begin{array}{c}\text { Total } \\
\text { Amount }\end{array}$ \\
\hline 1962 & 489 & 569 & 787 & 829 & 486 & 237 & 440 & 284 & 328 & 616 & 590 & 497 & 6179 \\
& $(7.9)$ & $(9.7)$ & $(12.7)$ & $(13.4)$ & $(7.9)$ & $(3.8)$ & $(7.1)$ & $(4.6)$ & $(5.3)$ & $(10.0)$ & $(8.6)$ & $(8.0)$ & $(100.0)$ \\
\hline 1965 & 768 & 1053 & 1317 & 1225 & 716 & 433 & 730 & 839 & 337 & 704 & 680 & 586 & 9388 \\
& $(8.2)$ & $(11.2)$ & $(14.0)$ & $(13.2)$ & $(7.6)$ & $(4.6)$ & $(7.8)$ & $(8.9)$ & $(3.6)$ & $(7.5)$ & $(7.2)$ & $(6.2)$ & $(100.0)$ \\
\hline 1970 & 2755 & 2816 & 3957 & 3603 & 3463 & 2236 & 4160 & 5042 & 3533 & 4555 & 4518 & 5332 & 45970 \\
& $(6.0)$ & $(6.1)$ & $(8.6)$ & $(7.8)$ & $(7.5)$ & $(4.6)$ & $(9.1)$ & $(11.1)$ & $(7.7)$ & $(9.9)$ & $(8.8)$ & $(11.6)$ & $(100.0)$ \\
\hline 1975 & 6895 & 6114 & 11415 & 7610 & 8641 & 4141 & 4528 & 8501 & 5718 & 11277 & 9626 & 9774 & 92440 \\
& $(7.5)$ & $(6.6)$ & $(12.3)$ & $(8.2)$ & $(7.4)$ & $(4.5)$ & $(4.9)$ & $(9.2)$ & $(6.2)$ & $(12.2)$ & $(10.4)$ & $(10.6)$ & $(100.0)$ \\
\hline 1980 & 10913 & 14431 & 17483 & 14658 & 11308 & 7938 & 10264 & 14134 & 9876 & 18318 & 17055 & 16519 & 162897 \\
& $(6.7)$ & $(8.9)$ & $(10.7)$ & $(9.0)$ & $(9.9)$ & $(4.9)$ & $(6.3)$ & $(8.7)$ & $(6.1)$ & $(11.2)$ & $(10.5)$ & $(10.1)$ & $(100.0)$ \\
\hline 1985 & 10478 & 13751 & 17768 & 14681 & 13248 & 9997 & 7901 & 11588 & 14248 & 24187 & 21048 & 22094 & 180989 \\
& $(5.8)$ & $(7.6)$ & $(9.8)$ & $(8.1)$ & $(7.3)$ & $(5.5)$ & $(4.4)$ & $(6.4)$ & $(7.9)$ & $(13.4)$ & $(11.6)$ & $(12.2)$ & $(100.1)$ \\
\hline 1990 & 19647 & 23828 & 28482 & 18101 & 13584 & 11619 & 13803 & 20179 & 21824 & 34975 & 23177 & 22666 & 254885 \\
& $(7.7)$ & $(9.3)$ & $(11.2)$ & $(7.1)$ & $(5.3)$ & $(4.6)$ & $(5.4)$ & $(7.9)$ & $(8.6)$ & $(13.7)$ & $(10.3)$ & $(8.9)$ & $(100.0)$ \\
\hline
\end{tabular}




\begin{tabular}{|c|c|c|c|c|c|c|c|c|c|c|c|c|c|}
\hline 1995 & $\begin{array}{c}22207 \\
(6.1)\end{array}$ & $\begin{array}{c}28240 \\
(7.8)\end{array}$ & $\begin{array}{c}34219 \\
(9.4)\end{array}$ & $\begin{array}{c}33994 \\
(9.4)\end{array}$ & $\begin{array}{c}27843 \\
(7.7)\end{array}$ & \begin{tabular}{|c}
25650 \\
$(7.1)$
\end{tabular} & $\begin{array}{c}23980 \\
(6.6)\end{array}$ & \begin{tabular}{|c|}
27686 \\
$(7.6)$
\end{tabular} & $\begin{array}{c}30569 \\
(8.4)\end{array}$ & $\begin{array}{l}46845 \\
(12.9)\end{array}$ & $\begin{array}{c}35782 \\
(9.8)\end{array}$ & $\begin{array}{c}26380 \\
(7.3)\end{array}$ & $\begin{array}{l}363395 \\
(100.0)\end{array}$ \\
\hline 2000 & $\begin{array}{c}25307 \\
(5.5)\end{array}$ & $\begin{array}{c}38959 \\
(8.4)\end{array}$ & $\begin{array}{c}44944 \\
(9.7)\end{array}$ & $\begin{array}{c}43635 \\
(9.4)\end{array}$ & $\begin{array}{c}28363 \\
(6.1)\end{array}$ & $\begin{array}{c}26933 \\
(5.8)\end{array}$ & $\begin{array}{c}24480 \\
(5.3)\end{array}$ & $\begin{array}{c}34670 \\
(7.5)\end{array}$ & $\begin{array}{c}43523 \\
(9.4)\end{array}$ & $\begin{array}{l}59195 \\
(12.8)\end{array}$ & $\begin{array}{l}52993 \\
(11.4)\end{array}$ & $\begin{array}{c}40644 \\
(8.8)\end{array}$ & $\begin{array}{l}463646 \\
(100.0)\end{array}$ \\
\hline 2001 & $\begin{array}{c}30454 \\
(8.4) \\
\end{array}$ & $\begin{array}{l}38680 \\
(10.7)\end{array}$ & $\begin{array}{l}46709 \\
(12.9)\end{array}$ & $\begin{array}{l}39083 \\
(10.8) \\
\end{array}$ & $\begin{array}{c}28345 \\
(7.8)\end{array}$ & $\begin{array}{c}31030 \\
(3.6) \\
\end{array}$ & $\begin{array}{c}18329 \\
(5.1) \\
\end{array}$ & $\begin{array}{c}25322 \\
(7.0)\end{array}$ & $\begin{array}{c}31170 \\
(8.6)\end{array}$ & $\begin{array}{l}41245 \\
(11.4)\end{array}$ & $\begin{array}{c}30282 \\
(8.4)\end{array}$ & $\begin{array}{c}18588 \\
(5.1)\end{array}$ & $\begin{array}{l}361237 \\
(100.0)\end{array}$ \\
\hline 2002 & $\begin{array}{c}17176 \\
(6.2) \\
\end{array}$ & $\begin{array}{c}20668 \\
(7.5) \\
\end{array}$ & $\begin{array}{l}28815 \\
(10.5)\end{array}$ & $\begin{array}{c}21253 \\
(7.7)\end{array}$ & $\begin{array}{c}(19887) \\
(6.9)\end{array}$ & $\begin{array}{c}17218 \\
(6.2)\end{array}$ & $\begin{array}{c}16621 \\
(6.0)\end{array}$ & \begin{tabular}{|c|}
21093 \\
$(7.7)$
\end{tabular} & $\begin{array}{c}23752 \\
(8.6)\end{array}$ & $\begin{array}{l}35272 \\
(12.8)\end{array}$ & $\begin{array}{l}28723 \\
(10.4)\end{array}$ & $\begin{array}{c}24990 \\
(9.1)\end{array}$ & $\begin{array}{l}257468 \\
(100.0)\end{array}$ \\
\hline 2003 & $\begin{array}{c}21215 \\
(6.3)\end{array}$ & $\begin{array}{c}24349 \\
(7.2)\end{array}$ & $\begin{array}{c}27737 \\
(8.2)\end{array}$ & $\begin{array}{c}25851 \\
(7.6)\end{array}$ & $\begin{array}{c}22704 \\
(6.7)\end{array}$ & $\begin{array}{c}20351 \\
(6.0)\end{array}$ & $\begin{array}{c}22661 \\
(6.7)\end{array}$ & $\begin{array}{c}27568 \\
(8.2)\end{array}$ & $\begin{array}{c}28724 \\
(8.5)\end{array}$ & $\begin{array}{l}45459 \\
(13.4)\end{array}$ & $\begin{array}{l}38398 \\
(11.4)\end{array}$ & $\begin{array}{c}33115 \\
(9.8)\end{array}$ & $\begin{array}{l}338132 \\
(100.0)\end{array}$ \\
\hline 2004 & $\begin{array}{c}30988 \\
(8.0)\end{array}$ & $\begin{array}{c}35631 \\
(9.2)\end{array}$ & $\begin{array}{l}44290 \\
(11.5)\end{array}$ & $\begin{array}{c}33514 \\
(8.7)\end{array}$ & $\begin{array}{c}26802 \\
(7.0)\end{array}$ & $\begin{array}{c}19793 \\
(5.1)\end{array}$ & $\begin{array}{c}24860 \\
(6.5)\end{array}$ & \begin{tabular}{|c|}
33162 \\
$(8.6)$
\end{tabular} & $\begin{array}{c}25496 \\
(6.6)\end{array}$ & $\begin{array}{l}43373 \\
(11.3)\end{array}$ & $\begin{array}{c}36381 \\
(9.4)\end{array}$ & $\begin{array}{c}31007 \\
(8.0)\end{array}$ & $\begin{array}{l}385297 \\
(100.0)\end{array}$ \\
\hline 2005 & $\begin{array}{c}25477 \\
(6.8) \\
\end{array}$ & $\begin{array}{c}20338 \\
(5.4)\end{array}$ & $\begin{array}{c}28875 \\
(8.0)\end{array}$ & $\begin{array}{c}23414 \\
(6.2)\end{array}$ & $\begin{array}{c}25541 \\
(6.8)\end{array}$ & $\begin{array}{c}22608 \\
(6.0)\end{array}$ & $\begin{array}{c}23996 \\
(6.4)\end{array}$ & $\begin{array}{c}36910 \\
(9.8)\end{array}$ & $\begin{array}{c}36066 \\
(9.6)\end{array}$ & $\begin{array}{l}51498 \\
(13.7)\end{array}$ & $\begin{array}{l}41505 \\
(11.1)\end{array}$ & $\begin{array}{l}38170 \\
(10.1)\end{array}$ & $\begin{array}{l}375398 \\
(100.0)\end{array}$ \\
\hline 2006 & $\begin{array}{c}28769 \\
(7.5)\end{array}$ & $\begin{array}{c}25728 \\
(6.7)\end{array}$ & $\begin{array}{c}36873 \\
(9.6)\end{array}$ & $\begin{array}{c}21983 \\
(5.7)\end{array}$ & $\begin{array}{c}22870 \\
(6.0)\end{array}$ & $\begin{array}{c}26210 \\
(6.8)\end{array}$ & $\begin{array}{c}25183 \\
(6.6)\end{array}$ & $\begin{array}{c}33150 \\
(8.6)\end{array}$ & $\begin{array}{c}33362 \\
(8.7)\end{array}$ & $\begin{array}{l}49670 \\
(12.9)\end{array}$ & $\begin{array}{l}44119 \\
(11.5)\end{array}$ & $\begin{array}{c}36009 \\
(9.4)\end{array}$ & $\begin{array}{l}383926 \\
(100.0)\end{array}$ \\
\hline 2007 & $\begin{array}{c}33192 \\
(6.3) \\
\end{array}$ & $\begin{array}{c}39934 \\
(7.6)\end{array}$ & $\begin{array}{l}54722 \\
(10.4)\end{array}$ & $\begin{array}{c}10942 \\
(7.8)\end{array}$ & $\begin{array}{c}35854 \\
(6.8)\end{array}$ & $\begin{array}{c}31316 \\
(5.9)\end{array}$ & $\begin{array}{c}35437 \\
(6.7)\end{array}$ & $\begin{array}{c}44683 \\
(8.5) \\
\end{array}$ & $\begin{array}{c}45552 \\
(8.6)\end{array}$ & $\begin{array}{l}70644 \\
(13.4)\end{array}$ & $\begin{array}{c}52273 \\
(9.9)\end{array}$ & $\begin{array}{c}42156 \\
(8.0)\end{array}$ & $\begin{array}{l}526708 \\
(100.0)\end{array}$ \\
\hline 2008 & $\begin{array}{c}36913 \\
(7.4)\end{array}$ & $\begin{array}{c}46675 \\
(9.3)\end{array}$ & $\begin{array}{l}58735 \\
(11.7)\end{array}$ & $\begin{array}{c}38475 \\
(7.7)\end{array}$ & $\begin{array}{c}30410 \\
(6.1)\end{array}$ & $\begin{array}{c}24349 \\
(4.9)\end{array}$ & $\begin{array}{c}25427 \\
(5.1)\end{array}$ & $\begin{array}{c}40011 \\
(8.0)\end{array}$ & $\begin{array}{c}41622 \\
(8.3) \\
\end{array}$ & $\begin{array}{l}66421 \\
(13.3)\end{array}$ & $\begin{array}{l}52399 \\
(10.5)\end{array}$ & $\begin{array}{c}38840 \\
(7.8)\end{array}$ & $\begin{array}{l}500277 \\
(100.0)\end{array}$ \\
\hline 2009 & $\begin{array}{c}29278 \\
(5.7)\end{array}$ & $\begin{array}{c}40617 \\
(7.8)\end{array}$ & $\begin{array}{c}49567 \\
(9.7)\end{array}$ & $\begin{array}{c}43337 \\
(8.5)\end{array}$ & $\begin{array}{c}30037 \\
(5.9)\end{array}$ & $\begin{array}{c}31749 \\
(6.2)\end{array}$ & $\begin{array}{c}30432 \\
(6.0)\end{array}$ & $\begin{array}{c}44174 \\
(8.7)\end{array}$ & $\begin{array}{c}42771 \\
(8.4)\end{array}$ & $\begin{array}{l}72522 \\
(14.2)\end{array}$ & $\begin{array}{l}54423 \\
(10.5)\end{array}$ & $\begin{array}{c}1049 \\
(8.0)\end{array}$ & $\begin{array}{l}509956 \\
(100.0)\end{array}$ \\
\hline 2010 & $\begin{array}{c}30645 \\
(5.1)\end{array}$ & $\begin{array}{c}49264 \\
(8.2) \\
\end{array}$ & $\begin{array}{l}63058 \\
(10.5)\end{array}$ & $\begin{array}{c}45509 \\
(7.5) \\
\end{array}$ & $\begin{array}{c}32542 \\
(5.4)\end{array}$ & $\begin{array}{c}33263 \\
(5.5)\end{array}$ & $\begin{array}{c}38991 \\
(6.5)\end{array}$ & $\begin{array}{c}54672 \\
(9.1)\end{array}$ & $\begin{array}{c}54848 \\
(9.1)\end{array}$ & $\begin{array}{l}79130 \\
(13.1)\end{array}$ & $\begin{array}{l}67537 \\
(11.2)\end{array}$ & $\begin{array}{c}50408 \\
(8.4)\end{array}$ & $\begin{array}{l}602867 \\
(100.0)\end{array}$ \\
\hline
\end{tabular}




\section{Trend of Tourists Length of Stay}

The tourists' length of stay in the country has important role in tourism development. Higher length of stay is more beneficial for the country. In Nepal shortest length of stay of tourists is recorded 7.92 days in 2002 and the longest 13.51 days in the year 2004 during the period 2000 and 2010. The average length of stay of tourists in Nepal is about 11.0 days. The trend shows stagnation around 11 days in the tourist's length of stay in the years 2007, 2008 and 2009. However, in the year 2010 it increased to 12.67 days. It seems that generally the tourists who come for mountain tourism activities have longer length of stay in Nepal.

Table No. 7: Length of Stay of Tourists Arriving in Nepal 2000 - 2010

\begin{tabular}{|c|c|}
\hline Year & Average Length of Stay (in Days) \\
\hline 2000 & 11.88 \\
\hline 2001 & 11.93 \\
\hline 2002 & 7.92 \\
\hline 2003 & 9.60 \\
\hline 2004 & 13.51 \\
\hline 2005 & 9.09 \\
\hline 2006 & 10.20 \\
\hline 2007 & 11.96 \\
\hline 2008 & 11.78 \\
\hline 2009 & 11.32 \\
\hline 2010 & 12.67 \\
\hline
\end{tabular}

Source : Nepal Tourism Statistics, 2010, Ministry of Tourists and Civil Aviation, Govt. of Nepal, 2010.

\section{Trend of Mode of Tourist Arrivals}

The available transport service, whether it may be air or land has a crucial factor to attract tourists in the country. More than 80 percent tourists came to Nepal by air transport. In the early years above 80 percent tourists uses air service while visiting Nepal and below 20 percent tourists they came by land transport service. However, the mode of transport of tourists visiting Nepal has changed since 2002. Since 2002, except the year 2003, below 80 percent tourists came by air and above 20 percent came via land. This may be due to the increasing road and transport facilities in the country. 
Table No. 8: Mode of Tourist Arrival in Nepal 1962-2010.

\begin{tabular}{|c|c|c|c|c|c|}
\hline \multicolumn{1}{|c|}{ Year } & \multicolumn{2}{|c|}{ By Air } & \multicolumn{2}{c|}{ By Land } & $\begin{array}{c}\text { Total } \\
\text { Arrivals }\end{array}$ \\
\hline & Number & $\%$ & Number & $\%$ & \\
\hline 1962 & & & & & 6179 \\
\hline 1965 & 8303 & 88.4 & 1085 & 11.6 & 9388 \\
\hline 1970 & 36508 & 79.4 & 9462 & 20.6 & 45970 \\
\hline 1975 & 78995 & 85.5 & 13445 & 14.5 & 92440 \\
\hline 1880 & 139387 & 85.6 & 23510 & 14.4 & 162897 \\
\hline 1885 & 151870 & 83.9 & 29119 & 16.1 & 180989 \\
\hline 1990 & 226421 & 88.8 & 28464 & 11.2 & 254885 \\
\hline 1995 & 325035 & 89.4 & 38360 & 10.6 & 363395 \\
\hline 2000 & 376914 & 81.3 & 86732 & 18.7 & 463464 \\
\hline 2001 & 299514 & 82.9 & 61723 & 17.1 & 361237 \\
\hline 2002 & 218660 & 79.4 & 56808 & 20.6 & 275468 \\
\hline 2003 & 275438 & 81.5 & 62694 & 18.5 & 338132 \\
\hline 2004 & 297335 & 77.2 & 87962 & 22.8 & 385297 \\
\hline 2005 & 277346 & 73.9 & 98052 & 26.1 & 375398 \\
\hline 2006 & 283819 & 73.9 & 100107 & 26.1 & 383926 \\
\hline 2007 & 360713 & 68.5 & 165992 & 31.5 & 526705 \\
\hline 2008 & 374661 & 74.9 & 125616 & 25.1 & 500277 \\
\hline 2009 & 379322 & 74.4 & 130634 & 25.6 & 509956 \\
\hline 2010 & 448800 & 74.4 & 154067 & 25.6 & 602867 \\
\hline
\end{tabular}

Source : Nepal Tourism Statistics, 2010, Ministry of Tourists and Civil Aviation, Govt. of Nepal, 2010.

\section{Conclusion}

Tourism, despite having a long history, has really appeared as the development form since the 1950s only, in Nepal. The trend of tourists visiting Nepal seems satisfactory; however, a rightful appropriation of potential resources to change the existing situation of the tourism industry shall be expedient. Tourism industry has emerged as a sector that contributes a lot to the country by creating jobs and by reaching development to remote and far off areas that has turned out a corner stone in alleviating poverty. Thus, to promote tourism sector and its contribution to socio-economic sector of the country, we need to utilize available resources properly and beneficially. For this, there is a need of dynamic 
and tourism friendly policy and joint effort of the government and the private sector as well.

\section{Endnote:}

1. Tourism Statistics show P.R. China as the second largest source of tourist arrival in the country in 2010. However, its data is included in the 'Others' category

\section{References}

Americana Corporation (1976), Encyclopedia Americana V61.26, New York.

Bhandari, Dhundi Raj (2030), Nepalko Yetihasik Bibechana, Varanasi: Krishna Kumari Devi.

Chhetri, Ganesh (Dr.) and Rayamajhi (2061), Paryatan : Bikash Ra Byabasthapan, Asia Publication, Kathmandu.

Gautam, Rajesh (2052), Yetihashik Sugauli Sandhi Kasari Lagoo Bhayo?, Gorkhapatra, 2052/2/1, Kathmandu.

Gurung, Harka (1978), 'Tourism Trends in Nepal', Industrial Digest, Kathmandu: Nepal Industrial Development Corporation, vol.8, No. 1.

K.C., Ram Bahadur (1984), Facts About Nepal, $H M G / N$, Department of Information, Kathmandu.

Pradhan, Bhuban Lal (2045), Nepal Ma Baudha Dharma, Nepal Rajkiya Pragya Pratisthan, Katmandu.

Ranjit, Sanu Raja (1976), Tourist Industry with Special Reference to Foreign Exchange Earnings and Resort Development (Unpublished Master's Dissertation) submitted to IBACPA, Tribhuvan University, Kathmandu.

Satyal, Yagna Raj (1988), Tourism in Nepal A Profile, Varanasi, India, Nath Publishing House,

Shaha, Rishikesh (1998), Heroes And Builders of Nepal, Delhi: Book Faith India.

Shakya, Din Kaji (2051), Nepalma Paryatan Udhyog, Kathmandu: Bhuvaneshwori Shakya.

Shakya, Shailendra Bahadur (1975), Tourist Industry A Source of Foreign Exchange (Unpublished Master's Dissertation) 
submitted to IBACPA, Tribhuvan University, Kathmandu.

Sharma, Bal Chandra (2033), Nepalko Yetihasik Roop Rekha, Varanasi: Krishna Kumari Devi.

Sherpa, Ang Tshering and Shrestha, Hari Prasad (2011), Mountain Tourism and Nepal's Mountain Tourism Policy : An Overview, PYC Nepal Journal of Management, Vol. IV, No. 1, August 2011, Public Youth Campus, Kathmandu, Nepal

Shrestha, Hari Prasad (1978), A Study on Factors Affecting the Tourist Influx in Nepal with Special Reference to Accommodation, Transportation and Publicity (Unpublished Master's Dissertation submitted to 1BACPA), Tribhuvan University, Kathmandu.

Shrestha, Hari Prasad (2000), Tourism In Nepal : Marketing Challenges, Nirala Publication, New Delhi, India.

UAAA (2007), Mountaineering in Asia : UAAA Past and Present, Japan.

${ }^{1}$ According to the chronology and writings of various other authors e.g. Waddel, Kirk Patrick (1811), and Oldfield (1889), Manjushree Bodhisatwa must be the first person arriving to this valley who cleared the water of the valley and established habitation. However, the chronology records the arrival of Bipashwi Buddha, Shikhi Buddha, Bishwabhu Buddha and Krakuchhand Buddha. For further see references Bal Chandra Sharma (2033), Dhundi Raj Bhandari (2030) etc. 